\title{
Customers' Perception of Bank Service Quality: The Importance of Employee Service Quality
}

\author{
K K Govender
}

Department of Economics, University of Transkei

\section{ABSTRACT}

In financial services marketing, especially among banks, there is limited opportunity to impress the customer because services are becoming more automated. This paper reports the findings of a mail survey using self- administered questionnaires, conducted among a random sample of 1050 bank customers. From a usable sample of 190 respondents, it was found that the customers' perception of the overall service quality [SQUAL] is positively associated with their perception of the bank employees' service quality [EQUAL]. This implies that service firm managers need to understand what kind of employee behaviour most effectively serves to satisfy customers, and also discover ways to foster such behaviour by their customer contact employees. An agenda for future research is proposed.

JEL M 21

\section{INTRODUCTION}

According to Bettencourt and Brown (1997: 39), in many services contact employees are the source of differentiation and competitive advantage. Customer satisfaction, service quality perception, and decisions either to remain loyal or to change service providers are significantly influenced by the attitude and behaviour of these company representatives. Mohr and Bitner (1995:240) assert that contact employees contribute to service excellence by delivering on the promises of the firm, creating a favourable image for the firm, and going beyond the call of duty for the customers. Despite their importance, these employees continue to be treated by many organizations as disposable resources (Bettencourt and Brown, 1997: 40). In view of this, the present research attempts to discover whether the customers' perception of employee service quality [EQUAL] is associated with their perception of the overall service quality [SQUAL]. 


\section{BRIEF THEORETICAL REVIEW AND HYPOTHESIS}

Julian and Ramaseshan (1994: 29) assert that because of the labour intensity of many services, quality can vary from one firm (branch) to another and from one situation to the next within the same firm.

Furthermore, too much emphasis on short-term profitability in a service firm may be reflected in lower service quality assessments by the customer. For example, a short-run view can lead to many cost-reducing moves and their consequences, such as reducing the number of bank tellers and lengthening the lines at the teller windows. High employee turnover, according to Berry, Bennett and Brown (1989: 10 ), can cause poor service, and service problems can in turn lead to high employee turnover.

Mohr and Bitner (1995: 239) assert that since services are intangible, in many cases the only tangible evidence (or cue) available to compare quality and performance in a service transaction is the contact person with whom they interact. By referring to the service employees as "part-time" marketers, Gummesson (1991:68) argues that during the product/service delivery process, the service providers, have a unique chance of influencing the customers' present and future purchases as they are in direct contact with the customers. Thus natural points of marketing occur which can be used to the advantage of the service provider.

Some researchers such as Larkin and Larkin (1996: 213-227) argue that information technology has made it possible to provide service that is personal, personalized and convenient. Information transmitted instantaneously throughout an organization can empower either the consumer or the service provider and in some cases both. Thus front-line employees are granted real authority that allows them better to help their customers at the point of initial customer contact.

While an industrialization approach to services, as suggested by some researchers (Chase, 1978: 137-142; Lovelock and Young, 1979: 168-178), may initially seem appealing, the service marketer is in danger of losing the customer orientation which is so vital during the interactive employee-customer service encounter. Moreover, advocates of the "technological" approach to the management of service performance may have ignored an important factor, namely, the level of sophistication achieved by the customer or target market. For example, if a bank operates in an area in which the majority of customers are illiterate or have only a low level of education, there is need for more personal interaction between bank 
employees and customers to conclude most transactions. Serving a semi-literate population segment is bound to result in many queries emanating from a lack of knowledge about or incorrect use of ATMs. By interacting with customers and responding to queries, bank employees are provided with "opportunities" to impress these customers.

Schneider and Bowen (1995: 7) proposed that service organizations should be viewed as comprising three tiers: the customer tier, the boundary tier, and the coordination tier. This way of thinking about the service organization has some unique features, in that management's task is not to "control" or "lead" employees to service excellence but to put together a system that actually makes it possible to deliver quality service.

It is apparent from the brief literature review above, that the in the service sector the contact person is often the main cue for the customer regarding the service being sold; for example, an insurance agent influences the consumer's perception of the insurance agency, as well as the insurance being sold.

Although many top managers who are seeking to improve company competitiveness are now producing plans calling for a stronger organizational commitment to high-quality customer service, less attention has been given to the effective implementation of these plans by customer-contact employees. Far removed from the strategic planning table and lacking much practical guidance, customer-contact managers and employees must translate top management service goals into action. All too often ambitious strategies for better service break down at the point of delivery, jeopardizing the organization's strategic plans and its very survival.

In the light of foregoing, it is hypothesized that:

$\mathrm{H}^{\prime}$ : The bank customers' perception of the overall service quality [SQUAL] is positively associated with their perception of the employee service quality [EQUAL].

$\mathrm{H}^{0}$ : The bank customers' perception of the overall service quality [SQUAL] is not associated with their perception of the employee service quality [EQUAL]. 


\section{METHODOLOGY}

\section{Sample, Research Setting and Response}

Using convenience and judgmental sampling techniques, a sample of 210 front-line employees of three major commercial banks in South Africa were selected to participate in this survey. The commercial banks were selected by means of simple random sampling.

The managers of three Eastern Cape branches were personally briefed about the research and they assisted by distributing questionnaires to customers through their front-line employees.

Each bank employee ( 70 per bank) was requested to hand five questionnaires (a sample of 1050 customers) together with postage paid envelopes to every third customer with whom they interacted for at least ten minutes. The rationale for choosing every third customer was to introduce a "sense of randomness" into the customer sample, a method which has been used in previous researchers such as Danaher and Mattsson (1993: 8) and Naumann and Giel (1995: 207-209).

By providing customers with stamped, self-addressed envelopes, it was hoped that this procedure might contribute to the bank customers responding freely and honestly to all questions. Anonymity was assured as no respondent was required to supply his or her name or bank account number.

After a three month period, only 190 usable questionnaires were returned. The unfavourable overall response rate (of 18.1 per cent) was to be expected, considering that customers could not be compelled to complete and return (post) the questionnaires.

Furthermore, banks could not identify customers to whom questionnaires were given since this was done randomly. However, notices to remind customers to complete and return the questionnaires were posted in the various banks. Table 1 reflects the frequency distribution of the respondents. 


\section{Table 1: Distribution of Respondents}

\begin{tabular}{|c|c|c|c|c|c|}
\hline Banks & $\begin{array}{c}\text { Employees } \\
\text { Selected }\end{array}$ & $\begin{array}{c}\text { Employee } \\
\text { Participation }\end{array}$ & $\begin{array}{c}\text { Customers } \\
\text { Surveyed }\end{array}$ & $\begin{array}{c}\text { Customer } \\
\text { Response }\end{array}$ & $\%$ \\
\hline A & 70 & 50 & 350 & 79 & 22.7 \\
\hline B & 70 & 26 & 350 & 63 & 18.0 \\
\hline C & 70 & 30 & 350 & 48 & 13.7 \\
\hline Total & $\mathbf{2 1 0}$ & $\mathbf{1 0 6}$ & $\mathbf{1 0 5 0}$ & $\mathbf{1 9 0}$ & $\mathbf{1 8 . 1}$ \\
\hline
\end{tabular}

\section{Research Instruments}

The customers' perception of the overall service quality (SQUAL) was measured using an adapted SERVQUAL instrument, due to research (Buttle, 1996: 8-32: Nel. Pitt and Berthon, 1997: 113-122) which identified deficiencies in the SERVQUAL instrument. In this study the instrument used was based on the 22 items of the SERVQUAL instrument; however, it combined expectations and perceptions into one measure by asking customers whether certain aspects of service quality exceeded or fell short of expectations. Customers were asked to rate each of the 22 items on a scale ranging from 1 (worse than expected) to 5 (better than expected). The overall SQUAL score was a summed average score. This approach is supported by researchers such as Cronin and Taylor (1992: 55-68) and Parasuraman et al. (1994: 210-230).

In order to measure the customers' perception of the employee service quality (EQUAL) an instrument [see Appendix A] was developed, based on the universal SERVQUAL instrument. Customers were required to think about their interaction with the bank employee and indicate their agreement to each of 16 items (EQI to EQ16) on a five point scale where $1=$ strongly disagree and $5=$ strongly agree. A high score would indicate that the respondent perceived the employee service quality as being high.

\section{Measurement Reliability and Validity}

Since a common procedure for assessing reliability via the internal consistency method is Cronbach's (1951) alpha (Steffens, 1995: 10), the computer programme SAS PROC.CORR (SAS Institute, 1990) was used to determine Cronbach's coefficient alpha of the measuring instruments. The SQUAL scale returned a Cronbach's coefficient alpha of 0.961 and the EQUAL scale 0.946 , which implied 
that these latent variables were measured with acceptable levels of reliability (Bless and Higson-Smith, 1995: 135).

As an initial step to address the question of validity, the measure development paradigms recommended by researchers such as Churchill (1995: 534-539) and Parasuraman (1991: 442-443) were closely followed during the development of the scales. Thereafter, Exploratory Factor Analysis (Willie 1996) was performed to ascertain the discriminant and construct validity of the measuring instruments.

In each step of the Exploratory Factor Analysis (EFA), individual items were deleted from the respective measuring instruments if the factor loadings were below 0.4 (Rummel, 1967). This process was repeated until all the (remaining) measuring instruments possessed acceptable levels of discriminant and construct validity. In each step of the analysis, BMDP4M (Frane, Jennrich \& Sampson 1993) was used to perform a maximum likelihood factor analysis with a direct quartimin rotation (Jennrich \& Sampson, 1966: 313-323) of the unrotated factor matrix.

Due to the fact that the latent variables SQUAL and EQUAL had too many measurements, it was decided to reduce the number of individual measurements by averaging individual measurements to generate adapted measurements. The final SQUAL instrument which comprised 16 items was refined as follows: SQ1 (SQ6+ $\mathrm{SQ7+SQ8+SQ9)/4;} \mathrm{SQ} 2$ (SQ1 1+SQ12+SQ13+SQ14)/4; SQ3 (SQ15+SQ16+SQ17 $+\mathrm{SQ18}) / 4 ; \mathrm{SQ} 4(\mathrm{SQ19+SQ20+SQ21+SQ22)/4.} \mathrm{The} \mathrm{EQUAL} \mathrm{instrument} \mathrm{which}$ was also refined as follows: $\mathrm{EQ} 2$ (EQ5+EQ6+EQ7)/3; $\mathrm{EQ} 3$ $(\mathrm{EQ} 8+\mathrm{EQ} 9+\mathrm{EQ} 10+\mathrm{EQ} 11) / 4 ; \mathrm{EQ} 4(\mathrm{EQ} 12+\mathrm{EQ} 13+\mathrm{EQ} 14+\mathrm{EQ} 15) / 4$ consisted of 11 items.

Table 2 reflects that the measuring instruments possess acceptable levels of discriminant and construct validity since they load with loadings above 0,4 (Rummel, 1967) only on one factor.

Table 2: $\quad$ Rotated Factor Loadings

\begin{tabular}{|c|c|c|}
\hline Item & $\begin{array}{c}\text { FACTOR 1 } \\
\text { Overall Service Quality }\end{array}$ & $\begin{array}{c}\text { FACTOR 2 } \\
\text { Employee ServiceQuality }\end{array}$ \\
\hline SQUAL 1 & -0.033 & $0.841^{*}$ \\
\hline SQUAL 2 & 0.013 & $0.924^{*}$ \\
\hline SQUAL 3 & 0.068 & $0.847^{*}$ \\
\hline SQUAL 4 & -0.001 & $0.944^{*}$ \\
\hline
\end{tabular}




\section{Table 2 continued}

\begin{tabular}{|c|c|c|}
\hline Item & $\begin{array}{c}\text { FACTOR 1 } \\
\text { Overall Service Quality }\end{array}$ & $\begin{array}{c}\text { FACTOR 2 } \\
\text { Employee ServiceQuality }\end{array}$ \\
\hline EQUAL 2 & $0.810^{*}$ & -0.046 \\
\hline EQUAL 3 & $0.972^{*}$ & -0.000 \\
\hline EQUAL 4 & $0.842^{*}$ & 0.026 \\
\hline
\end{tabular}

\section{Data Analysis}

Exploratory data analysis was conducted using the SAS (SAS Institute, 1990) computer programme. More specifically, the univariate, general linear model and correlation procedures were performed. To further empirically evaluate the hypothesized relationship depicted in Figure 1, the computer programme RAMONA (Brown and Mels 1990) was used.

Figure 1: Hypothesized Model

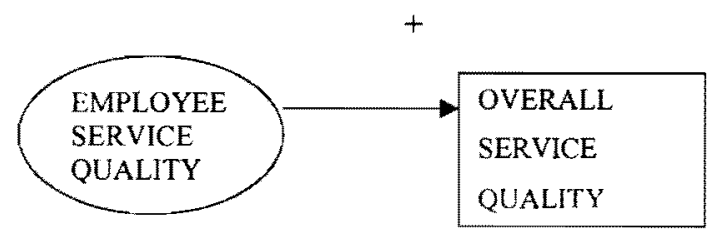

\section{EMPIRICAL FINDINGS}

The initial descriptive results using the SAS (SAS Institute, 1990) computer programme and the PROC. UNIVARIATE procedure are summarized in Table 3.

The favourable overall SQUAL (4.1047) and EQUAL (4.116) scores implied that the banks concemed were offering quality service to its customers. However, the low response rate, the large kurtosis values (greater than 0 ) and the skewness implied that non parametric tests had to be used to analyze the data. 


\section{Table 3: Univariate Data Analysis}

\begin{tabular}{|l|c|c|}
\hline & SQUAL & EQUAL \\
\hline N & 190 & 190 \\
Mean & 4.1048 & 4.1164 \\
Std. Dev. & 0.7946 & 0.8278 \\
Skewness & -0.9819 & -2.2713 \\
Kurtosis & 0.9409 & 8.7428 \\
Variance & 0.6314 & 0.6853 \\
Pr $|\mathrm{T}|$ & 0.0001 & 0.0001 \\
\hline
\end{tabular}

The PROC GLM. procedure, with SQUAL as the dependent variable and EQUAL as the independent variable produced a $\mathrm{R}^{2}$ of 0.2655 , a $\mathrm{CV}$ of 16.63339 and a RMSE of $0.6828, F$ Value of 67.98 and a Pr $>F$ of 0.0001 . The PROC CORR. procedure produced a Pearson correlation coefficient of 0.5153 , and a Spearman's correlation coefficient of 0.6045 , both of which implied that there is a positive association between overall service quality and employee service quality. Furthermore, the covariance matrix of 0.3390 suggested a need to conduct further analysis so as to ascertain the determinant in the model.

The hypothesized model (Figure 1) was also fitted to the observed data, using the computer programme RAMONA (Browne and Mels, 1990) by specifying an analysis based on sample correlation matrix with maximum likelihood estimation. The resulting maximum likelihood estimate with the associated significance information in terms of $\mathrm{p}$ values is shown in Figure 2.

It is evident from Figure 2 that the overall service quality (as measured by SPE) is significantly influenced by the employee service quality $(0.552 ; \mathrm{p}<0.01)$. This implies that the service quality delivered by the banks' employees to their customers is a very important determinant of the overall service quality delivered by the banks. Thus the hypothesis in this study is supported and the null hypothesis is obviously rejected.

The hypothesized model (Figure1) provided a reasonable fit to the data as was evident by the Root Mean Square Error of Approximation of 0.068 . This result was further supported by the fact that the Expected Cross Validation Index for the model (3.046) was less that that for the saturated model (3.345). 
Figure 2: Empirical Evaluation of Hypothesized Model

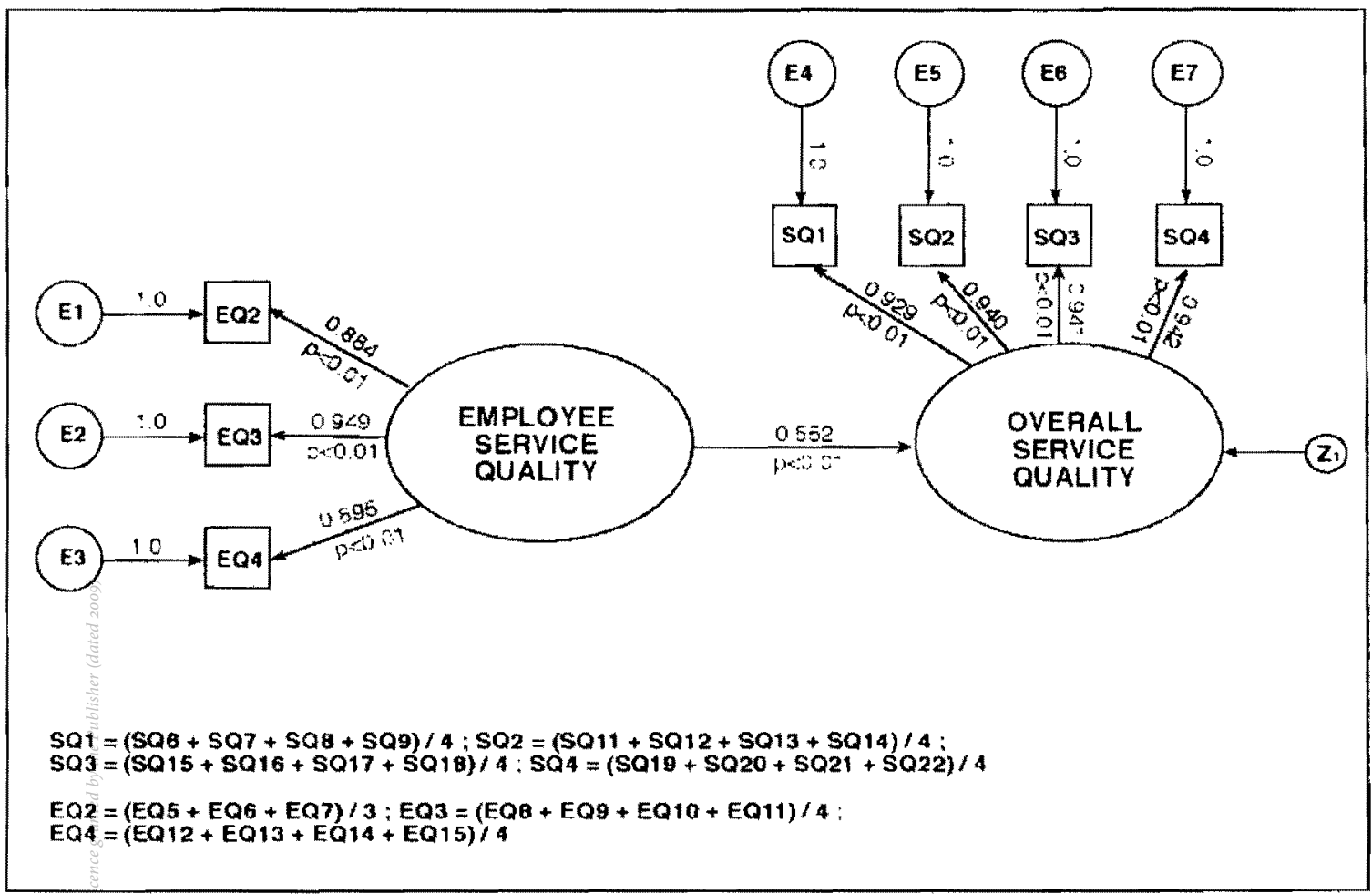




\section{DISCUSSION AND MANAGERIAL IMPLICATIONS}

It emerged that when evaluating service quality, the consumer considers the service delivery process as well as the service outcome. With reference to the delivery process, the importance of the service delivery personnel has been highlighted. This finding has been supported by previous research undertaken by Gronroos (1984: 36-44). This researcher maintained that in service businesses, the consumer is not only interested in "what" he receives as an outcome of the production process, but in the process itself. "How" he gets the technical outcome or technical quality is also important to him, and his view of the service he has received. Gronroos' view has also received empirical support from researchers such as Ennew, Reed and Martin (1993: 59) and Cronin and Taylor (1994: 125).

Since service employees are both physically and psychologically close to the customers they serve, they play at least two important roles, namely, impression managers and gatekeepers of information. For many customers, the service employee is the organization. This means that the "boundary" employees' behaviour, and the experiences their behaviour creates for the customers, are service quality in the eyes of the customer. Moreover, boundary employees, being in constant contact with customers, are an endlessly useful source of insights into customer attitudes, information on competitor strategies and ideas about how to enhance service quality. Moreover, Schneider and Bowen (1995:4) argue that the "make-it-or-break-it" role service employees play is that of linking customers to the organization.

Seeing that services marketing in the $21^{\text {st }}$ century is likely to be characterized by "high touch" through "high tech" strategies, organizations need to understand what employee behaviours most effectively serve to satisfy customers and also find ways to foster these behaviours in their customer contact employees.

\section{LIMITATIONS OF THIS STUDY AND FUTURE RESEARCH}

Although this exploratory study highlighted the importance of the service employee in customer evaluation of the overall service quality, much remains to be explained in terms of employee behaviour. The ongoing debate about the empowerment of service workers; Why, How, When, and to What effect, should be addressed through future research. 
In order to improve the response rate, customers could be interviewed in the bank immediately after their interaction with the service employee. Furthermore, to increase its generalizability, this study should be replicated in different research settings (service and non-service), and among a larger sample.

\section{REFERENCES}

1. BERRY, L.L., BENNETT, D.R. \& BROWN, C.W. (1989), Service Quality: A Profit Strategy for Financial Institutions. Homewood, Ill: Dow Jones.

2. BETTENCOURT L.A. \& BROWN, S.W. (1997), "Contact Employees: Relationships Among Workplace Fairness, Job Satisfaction and Pro-social Behaviours", Journal of Retailing, 73(1): 10-17.

3. BLESS, C. \& HIGSON-SMITH, C. (1995), Fundamentals of Social Research Methods: An African Perspective. 2nd ed. Kenwyn, Cape Town: Juta.

4. BROWNE, M.W. \& MELS, G. (1990), RAMONA PC User's Guide. Unpublished Report. Pretoria: Human Sciences Research Council.

5. BUTTLE, F. (1996), "Is there a role of Expectations in SERVQUAL?" Working Paper No. 305. UK: Manchester Business School,

6. CHASE, R.B. (1978), "Where Does the Customer Fit in the Service Operation?" Harvard Business Review, 56: 137-142.

7. CHURCHILL, G.A., Jr. (1995), Marketing Research: Methodological Foundations. 6th ed. Florida: Dryden.

8. CRONBACH, L.J. (1951), "Coefficient Alpha and the Internal Structure of Tests", Psychometrika, 16(3): 297-334.

9. CRONIN, J.J., JR.\& TAYLOR, S.A. (1992), "Measuring Service Quality: A Re-examination and Extension", Journal of Marketing, 56: 55-68.

10. CRONIN, J.J., Jr. \& TAYLOR, D.A. (1994), "SERVPERF versus SERVQUAL: Reconciling Performance Based and Perceptions-Minus Expectations Measurement of Service Quality", Journal of Marketing, 58: 125-131.

11. DANAHER, P.J. \& MATTSON, J. (1994), "Customer Satisfaction during the Service Delivery Process", European Journal of Marketing, 28(5): 5-16.

12. ENNEW, C.T., REED. G.V \& BINKS, M.R. (1993), "ImportancePerformance Analysis and the Measurement of Service Quality", European Journal of Marketing, 27(2): 59-70.

13. FRANE, J., JENRICH, R.I. \& SAMPSON, P.F. (1990), "4M-Factor Analysis". In Dixon, W.J. et al. (eds.). BDMP Statistical Software Manual, 
Vol. 1. Berkeley: University of California.

14. GRONROOS, C. (1984), "A Service Quality Model and Its Marketing Implications", European Journal of Marketing, 18(4): 36-44.

15. GUMMESSON, E. (1991), "Marketing Orientation Revisited: The Crucial Role of the Part-time Marketer", European Journal of Marketing, 25(2): 1121.

16. JENRICH, R.I. \& SAMPSON, P.F. (1966), "Rotation of Simple Loadings", Psychometrika, 31: 313-323.

17. JULIAN, C.C. \& RAMASESHAN, B. (1994), "The Role of CustomerContact Personnel in the Marketing of a Retail Bank's Services". International Journal of Retail and Distribution Management, 22(5): 15-28.

18. LARKIN, T.J. \& LARKIN, S. (1996), "Reaching and Changing Front-line Employees", Harvard Business Review, 105: 95-104.

19. LOVELOCK, C.H., \& AND YOUNG, R.F. (1979), "Look to Customers to Improve Productivity", Harvard Business Review, 57: 168-178.

20. MOHR, L.A. \& BITNER, M.J. (1995), "The Role of Employee Effort in Satisfaction with Service Transactions", Journal of Business Research, 32(3): 239-252.

21. NAUMAN, E. \& GIEL, K. (1995), Customer Satisfaction Measurement and Management: Using the Voice of the Customer. Cincinnati, Ohio: Thompson.

22. NEL, D., PITT, L.F. \& BERTHON, P.R. (1997), "The SERVQUAL Instrument: Reliability and Validity in South Africa", South African Journal of Business Management, 28(3): 113-122.

23. PARASURAMAN, A. (1991), Marketing Research. 2nd.ed. Massachusetts: Addison-Wesley.

24. PARASURAMAN, A., ZEITHAML, V.A. \& BERRY, L.L. (1994), "A Reassessment of Expectations as a Comparative Standard in Measuring Service Quality: Implications for Future Research", Journal of Marketing, 58: 111-124.

25. RUMMEL, R.J. (1967), "Understanding Factor Analysis", Journal of Conflict Resolution, 11: 444-480.

26. SAS INSTITUTE INC. (1990), User's Guide, Release 6.03, Cary, N.C.: SAS Institute Inc,

27. SCHNEIDER, B.\& BOWEN, D.E. (1995), Winning The Service Game. Boston: Harvard Business School Press.

28. STEFFENS, F.E. (1995), Initial Data Analysis. Pretoria: Centre for Statistics, Human Sciences Research Council. 
29. WILLE A.S., 1996, A Stepwise Procedure for the Empirical Assessment of Latent Variable Models. Unpublished M.Sc. dissertation, Port Elizabeth: University of Port Elizabeth.

\section{APPENDIX A}

With regard to the BANK EMPLOYEE who served you, please indicate the degree of your agreement or disagreement with the following: $1=$ STRONGLY DISAGREE; $2=$ DISAGREE; $3=$ NEUTRAL; $4=$ AGREE; $5=$ STRONGLY AGREE.

THE BANK EMPLOYEE:

\begin{tabular}{|l|l|l|l|l|l|l|}
\hline EQ1 & Was neatly attired & 1 & 2 & 3 & 4 & 5 \\
\hline EQ2 & Understood your needs & 1 & 2 & 3 & 4 & 5 \\
\hline EQ3 & Was willing to help & 1 & 2 & 3 & 4 & 5 \\
\hline EQ4 & Was courteous & 1 & 2 & 3 & 4 & 5 \\
\hline EQ5 & Was prompt & 1 & 2 & 3 & 4 & 5 \\
\hline EQ6 & Gave you personal attention & 1 & 2 & 3 & 4 & 5 \\
\hline EQ7 & Treated your transaction confidentially & 1 & 2 & 3 & 4 & 5 \\
\hline EQ8 & Was able to answer queries & 1 & 2 & 3 & 4 & 5 \\
\hline EQ9 & Delivered on promises & 1 & 2 & 3 & 4 & 5 \\
\hline EQ10 & Had your best interest at heart & 1 & 2 & 3 & 4 & 5 \\
\hline EQ11 & Was sincere in solving your problem/s & 1 & 2 & 3 & 4 & 5 \\
\hline EQ12 & Performed the service right the first time & 1 & 2 & 3 & 4 & 5 \\
\hline EQ13 & $\begin{array}{l}\text { Was never too busy to respond to your } \\
\text { requests }\end{array}$ & 1 & 2 & 3 & 4 & 5 \\
\hline EQ14 & $\begin{array}{l}\text { Told you exactly when the service will be } \\
\text { performed. }\end{array}$ & 1 & 2 & 3 & 4 & 5 \\
\hline EQ15 & $\begin{array}{l}\text { Made you feel safe in conducting your } \\
\text { transaction }\end{array}$ & 1 & 2 & 3 & 4 & 5 \\
\hline EQ16 & Used language which you could understand & 1 & 2 & 3 & 4 & 5 \\
\hline
\end{tabular}

